\title{
Intravascular lymphomatosis presenting as skin lesions and subacute encephalopathy
}

\author{
INIMIOARA MIHAELA COJOCARU ${ }^{1,2}$, ADINA MITRU ${ }^{1}$, DANA NICA ${ }^{2,3}$, CARMEN MARIA ARDELEANU $^{2,4}$ \\ ${ }^{1}$ Department of Neurology, "Colentina” Clinical Hospital \\ 2“"Carol Davila" University of Medicine and Pharmacy, \\ ${ }^{3}$ Department of Dermatology, "Colentina" Clinical Hospital \\ 4،"Victor Babeş" National Institute for Research and Development in the Domain of Pathology, Bucharest, Romania
}

\begin{abstract}
Intravascular lymphomatosis is a neoplastic multisystemic disease; it is a rare subtype of diffuse large cell lymphoma characterized by the presence of lymphoma cells in the lumina of small vessels. A 49-year-old Caucasian woman was admitted to the Department of Internal Medicine for fatigue, night sweats, loss of weight, and multiple nodules in the forearms. Three months ago the patient's family noticed problems with her cognitive function, she displayed difficulties with common daily tasks. The neurological examination revealed bradypsychia. Laboratory data showed modestly high levels of lactate dehydrogenase, and C-reactive protein. The day after admission, the patient had headache which raised in intensity; his mental status deteriorated, she was disoriented to time and place. She presented nucal rigidity. The CSF examination revealed a hemorrhagic aspect, elements $30 / \mathrm{mm}^{3}$, cytology: lymphocytes $90 \%$, numerous erythrocytes, proteinorachia $96 \mathrm{mg} / \mathrm{dL}$, glycorrachia $60 \mathrm{mg} / \mathrm{dL}$. Intravenous Methylprednisolone ( $0.5 \mathrm{~g}$ two times a day) and Mannitol 20\% $1 \mathrm{~g} / \mathrm{kgw} / \mathrm{day}$ were administered for five days without response. She became comatose and she died six days after hospitalization. The post-mortem macroscopical brain examination showed a swallen brain, with diffuse hemorrhagic areas in the supratentorial subcortical regions. Microscopical examination showed capillaries, venules, and many arterioles distended by large malignant cells suggesting malignant lymphocytes which were intraluminal. Every organ was involved, except for bone marrow and lymph nodes. Immunohistochemical studies showed intensive staining for B cells and negative staining for factor VIII related antigen, a specific endothelial cell marker. Intravascular lymphomatosis was the post-mortem diagnostic. It represents a difficult diagnostic challenge which involves laboratory, imagistic and immunohistochemical investigations.
\end{abstract}

Keywords: intravascular lymphomatosis, subacute encephalopathy, skin lesions.

Intravascular lymphomatosis is a neoplastic multisystemic disease; it is a rare subtype of diffuse large cell lymphoma characterized by the presence of lymphoma cells in the lumina of small vessels [1].

Clinical presentation is proteinaceous. Antemortem diagnosis is challenging and frequently impossible. Early diagnosis and treatment before disease dissemination is very difficult but increases survival and remission.

\section{CASE PRESENTATION}

We present the case of a 49 -year-old righthanded Caucasian woman who was admitted to the Department of Internal Medicine for fatigue, night sweats, loss of weight (10 kilograms in three months), and multiple nodules in the forearms. She had no previous medical history three months before admission. Three months ago the patient's family noticed problems with her cognitive function, she displayed difficulties with common daily tasks. Multiple nodules were observed in the forearms. A neurological examination was normal, excepting bradypsychia.

Laboratory data, including blood cell counts and biochemistry were almost within normal limits, except for modestly high levels of lactate dehydrogenase (LDH $420 \mathrm{IU} / \mathrm{L}$ ), and C-reactive protein (CRP $14 \mathrm{mg} / \mathrm{L}$ ). The results of coagulation tests were normal.

The day after admission, the patient had headache which raised in intensity; over the next few days his mental status deteriorated, she was disoriented to time and place. She presented nucal rigidity. The electroencephalogram revealed generalized delta-theta slowing. 
The CSF examination revealed a hemorrhagic aspect, elements $30 / \mathrm{mm}^{3}$, cytology: lymphocytes $90 \%$, numerous erythrocytes, proteinorachia $96 \mathrm{mg} / \mathrm{dL}$, glycorrachia $60 \mathrm{mg} / \mathrm{dL}$.

A contrast-enhanced CT of the chest, abdomen, and pelvis failed to reveal any abnormal lesions. The dermatologic examination recommended a skin biopsy, but the patient's family did not agree with it.

Intravenous Methylprednisolone ( $0.5 \mathrm{~g}$ two times a day) and Mannitol 20\% 1g/kgw/day were administered for five days without response. The patient became increasingly less responsive. The clinical course worsened by the development of an upper gastrointestinal bleed. She became comatose and she died six days after hospitalization before any specific treatment.
The post-mortem macroscopical brain examination showed a swallen brain, blood in the subarachnoid space, diffuse hemorrhagic areas in the supratentorial subcortical regions.

Microscopical examination showed capillaries, venules, and many arterioles distended by large malignant cells with nucleoli and eosinophilic cytoplasm, suggesting malignant lymphocytes (Figures $2,3)$. The malignant cells were intraluminal.

Every organ was involved, except for bone marrow and lymph nodes (Figure 4).

Immunohistochemical studies showed intensive staining for B cells (B-cell-associated antigens, such as CD20 and CD79a) (Figures 5-7) and negative staining for factor VIII related antigen, a specific endothelial cell marker (Figure 8).

The final diagnosis was established: Intravascular lymphomatosis.

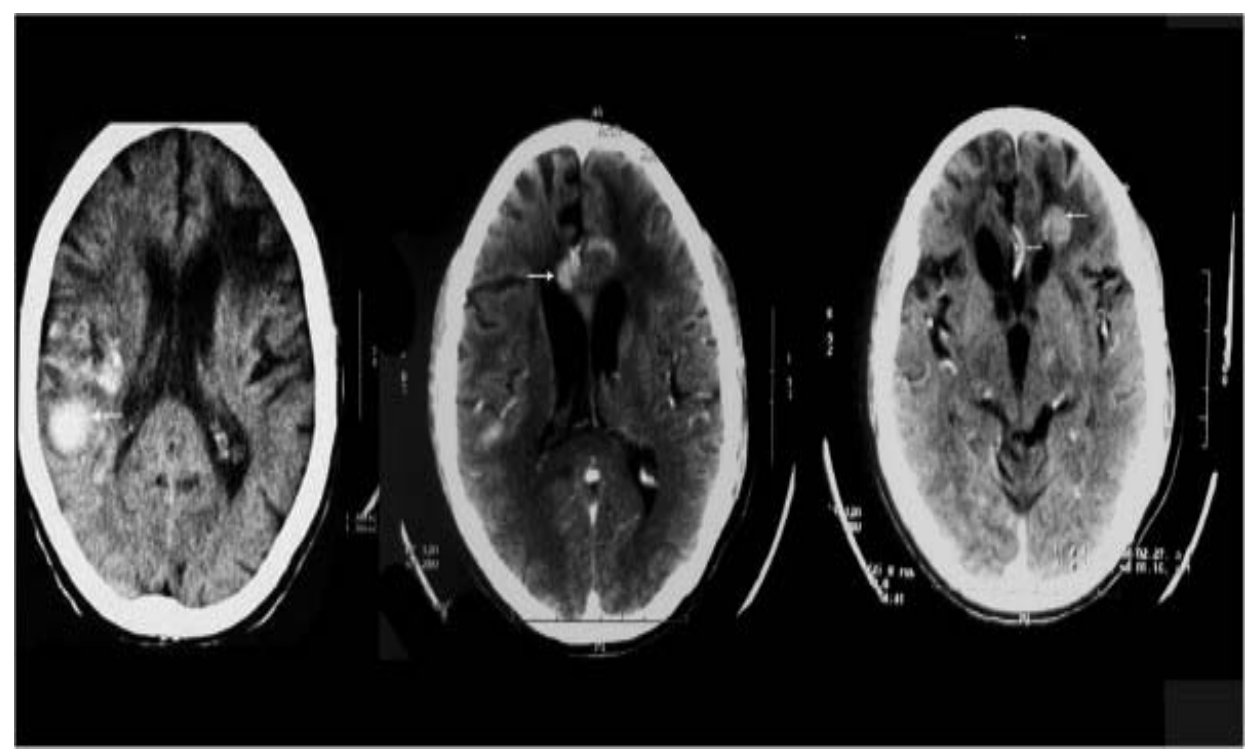

Figure 1. Cerebral CT examination-multiple hyperdense supratentorial subcortical lesions.

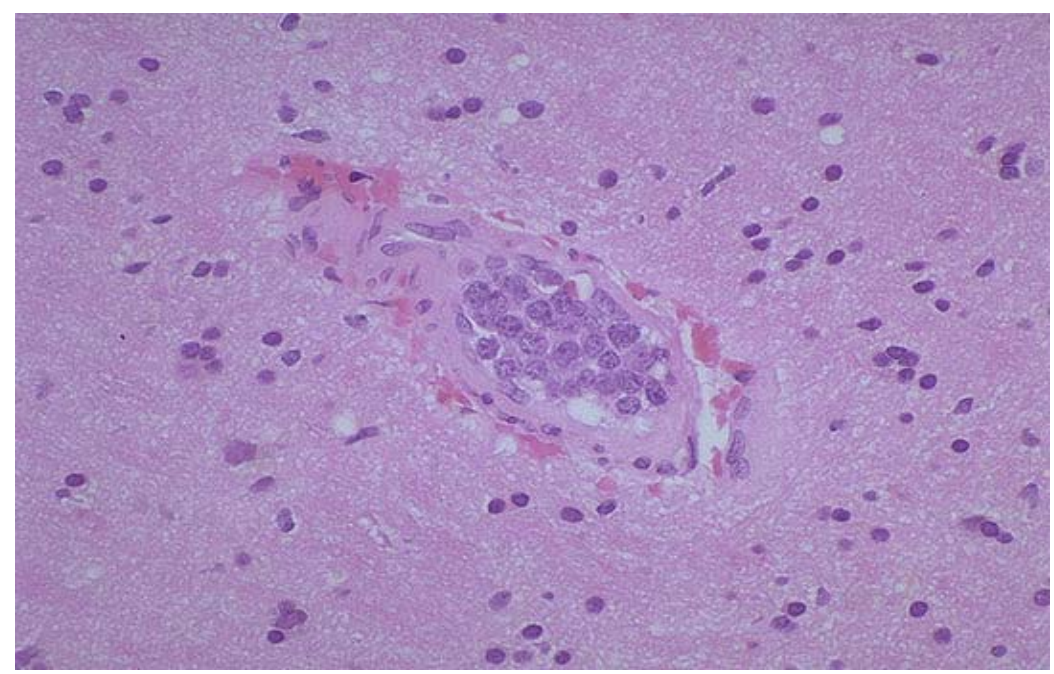

Figure 2. Cerebral intravascular lymphomatosis $(\mathrm{H}-\mathrm{E}, \mathrm{OM} \times 100)$. 


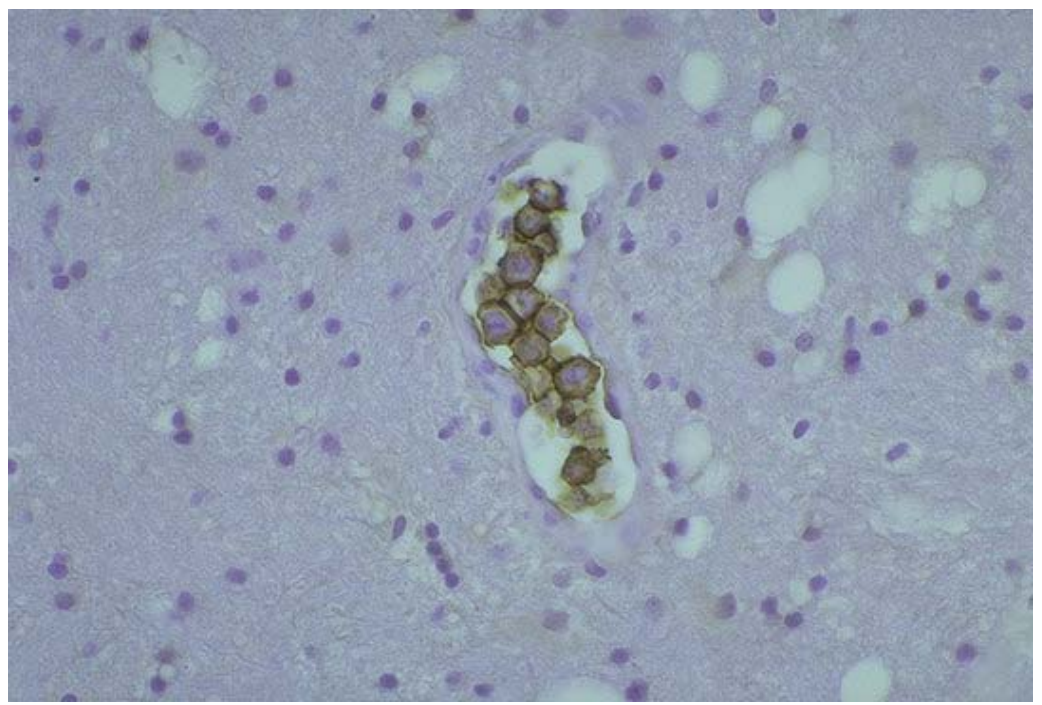

Figure 3. Cerebral intravascular lymphomatosis - a section stained immunohistochemically with an antibody to the CD20 marker, which stains B cells; positive rim of staining.

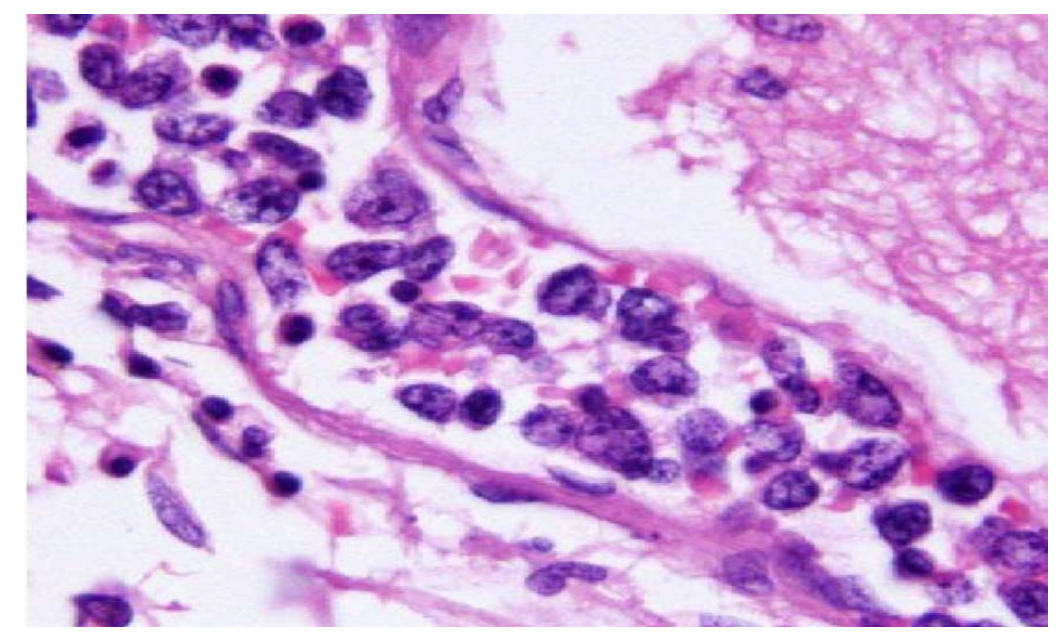

Figure 4. Skin intravascular lymphomatosis-blood vessels are occluded and distended by neoplastic lymphoid cells $(\mathrm{H}-\mathrm{E}, \mathrm{OM} \times 200)$.

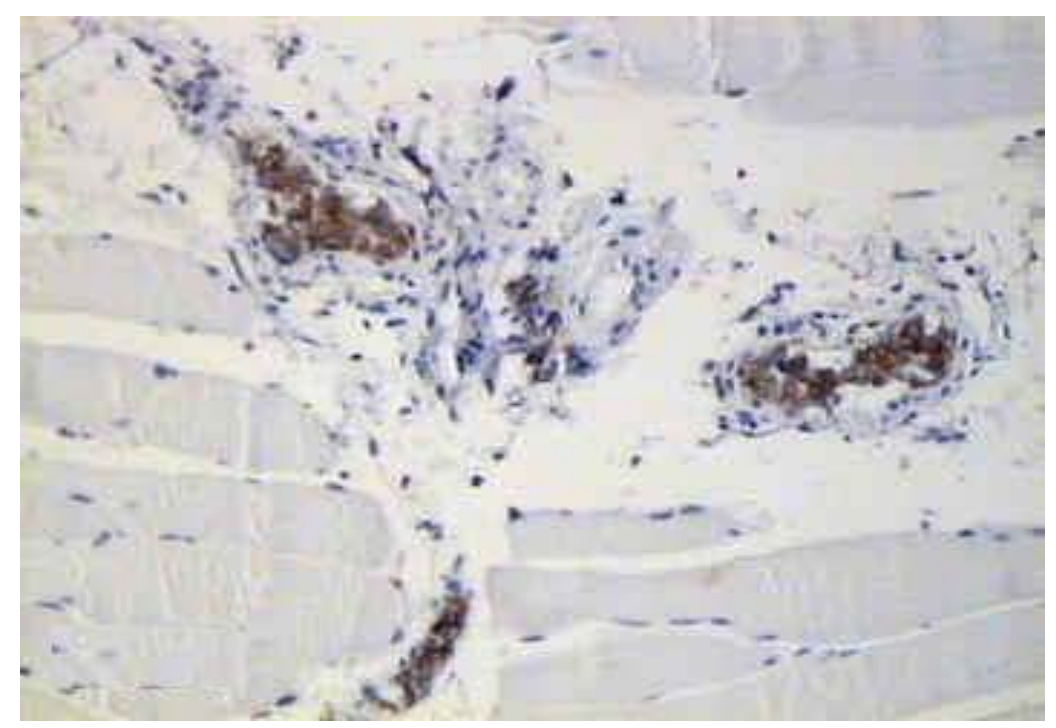

Figure 5. Cerebral intravascular lymphomatosis - a section stained immunohistochemically with an antibody to the CD79a marker, which stains B cells. 


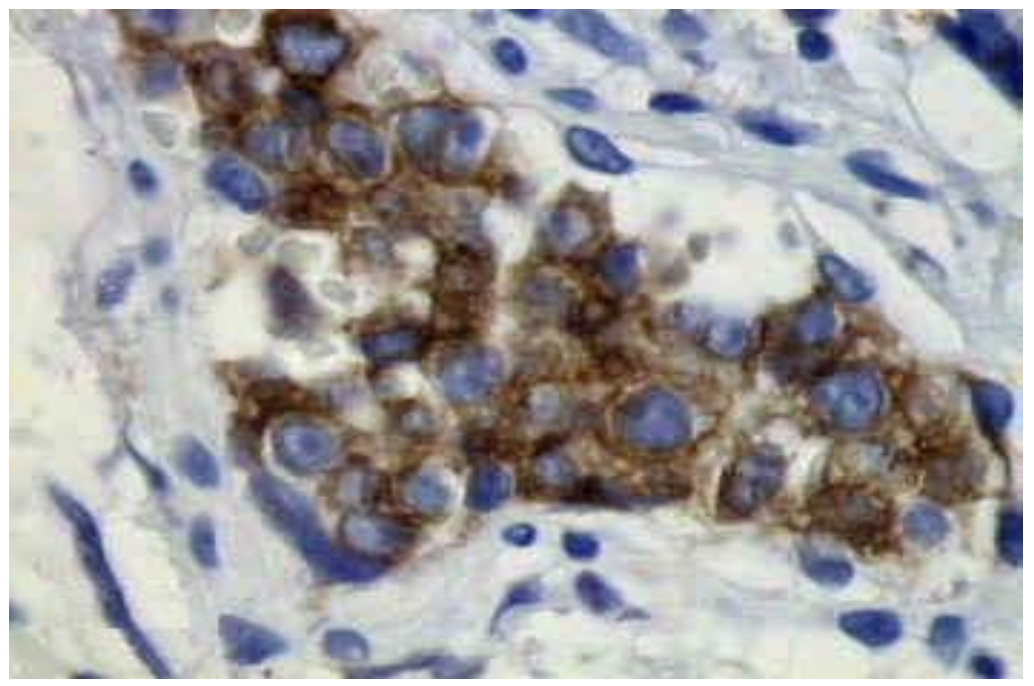

Figure 6. Cerebral intravascular lymphomatosis-a section stained immunohistochemically with an antibody to the CD79a marker, which stains B cells (enlarged view).

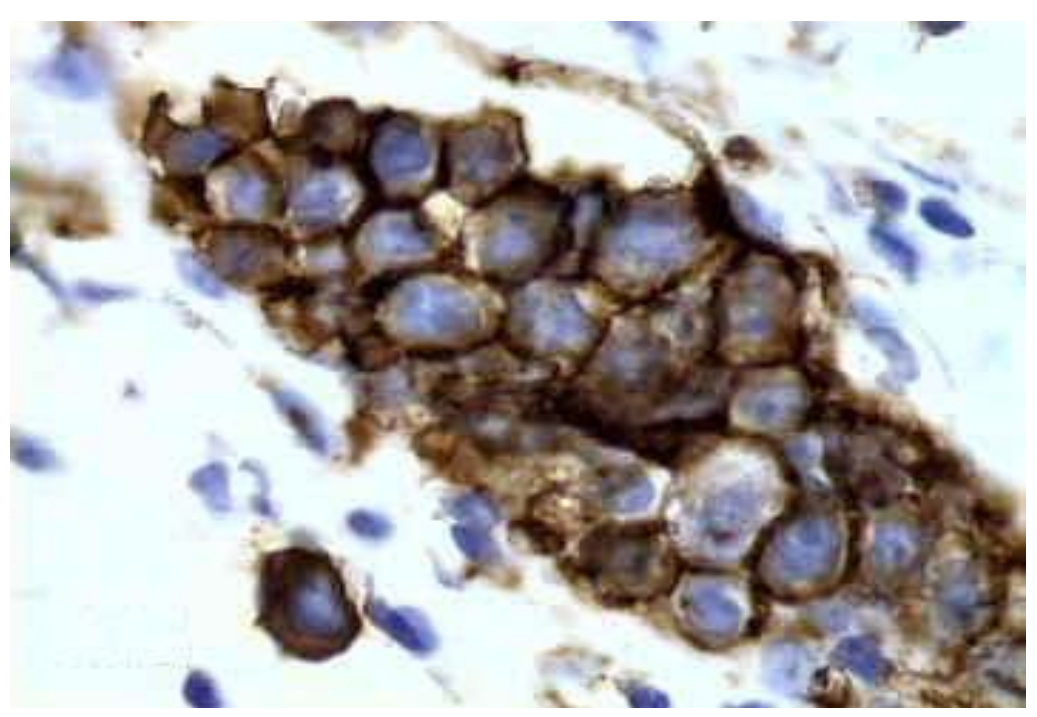

Figure 7. Cerebral intravascular lymphomatosis - a section stained immunohistochemically with an antibody to the CD20 marker, which stains B cells (enlarged view).

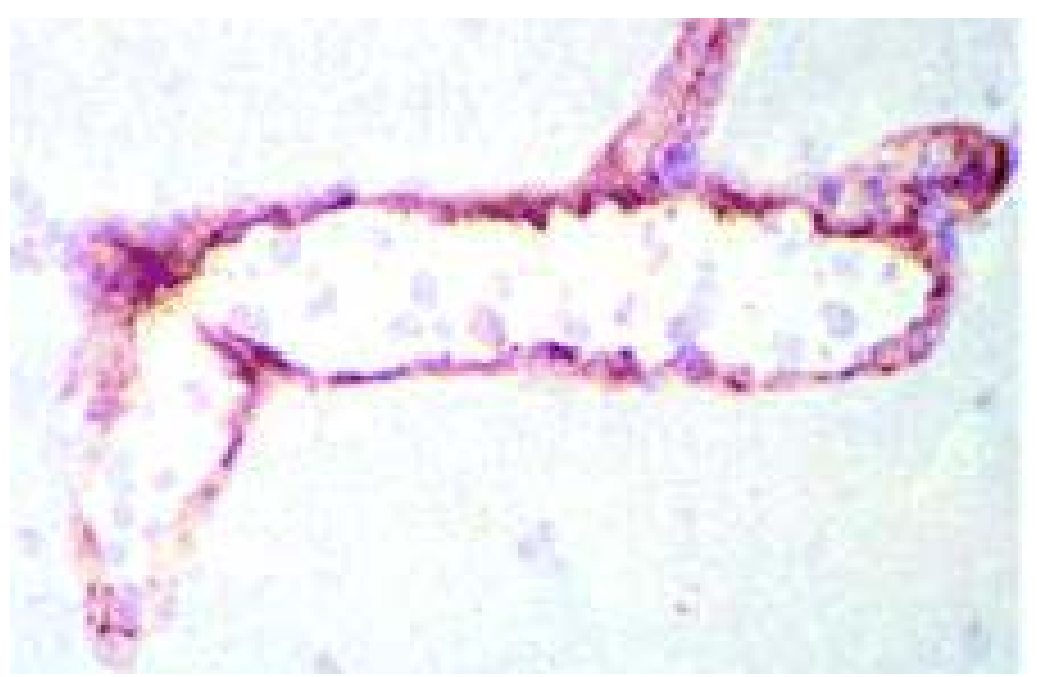

Figure 8. Cerebral intravascular lymphomatosis - a section stained immunohistochemically with an antibody to the factor VIII marker, which stains the vessel wall. 


\section{DISCUSSION}

Intravascular lymphomatosis is regarded by the WHO as a rare subset of diffuse large B-cell lymphoma (DLBCL), characterized by the proliferation of atypical lymphoid cells in the lumina of small vessels in various organs with little or no involvement of the organ parenchyma [1].

The disease was first described in 1959 by Pfleger and Tappeinner in Germany as "angioendotheliomatosis proliferans systemisata". It was described using many terms over the years: angioendotheliomatosis proliferans systemica, malignant angioendotheliomatosis, intravascular lymphomatosis, Kiel Classification: angio-endotheliotropic (intravascular) lymphoma, Lukes-Collins Classification: angiotropic large cell lymphoma, REAL Classification: diffuse large B-cell lymphoma (REAL-Revised EuropeanAmerican Lymphoma).

Intravascular large B-cell lymphoma (IVLBCL) is not defferent from B-IVL or T-OVL in a biologic sense and IVL seems to be better terminology than IVLBCL. It includes the T-cell phenotype that constitutes $9 \%$ of cases [2].

The disease involves several organs such as the brain and skin, whereas the spleen, lymph nodes and bone marrow are generally spared [3-5].

Recently, it has been suggested that intravascular lymphomatosis might have a predilection not only for the vessels but also for both the central nervous system (CNS) and peripheral nervous system (PNS) [6, 7].

The predilection of the tumor cells for capillary endothelium is likely related to the expression of molecules on the surface of lymphocytes that allows for preferential binding within the vascular channel. Aberrant expression of CD11a and CD49d (VLA-4) on intravascular lymphomatosis cells has been proposed as a possible mechanism because these adhesion molecules would enable tumor cells to home CD54 (CD11 a ligand) and CD106 (CD49d ligand), which are expressed on the endothelial cell surface [8].

Another study demonstrated that intravascular lymphomatosis cells were consistently lacking in CD29 ( $\beta_{1}$ integrin) and CD54 (ICAM-1), both of which are regarded as essential for lymphocyte homing and transvascular migration [9].

Immunohistochemically, tumor cells usually express B-cell-associated antigens, such as CD19, CD20, CD22 and CD79a. Several cases have been reported to express CD5. A T-cell phenotype of intravascular lymphomatosis is reported in rare cases and it has shown a coexpression of CD5 [1, $8,10]$.

Clinical presentation are CNS involvement (some patients may also present with myopathy and peripheral neuropathy, cutaneous involvement, fever of unknown origin, and hemophagocytic syndrome $[11,12]$.

The neurologic symptoms consist in focal sensory and motor deficits, stroke-like episodes, generalized weakness, altered senzorium, rapidly progressive dementia, seizures, dysarthria, ataxia, vertigo, transient visual loss, peripheral neuropathy, polyradiculopathy, myopathy and myelopathy [1329].

Neurological intravascular malignant lymphomatosis symptoms were divided into four groups: 1) progressive, multifocal cerebrovascular events, 2) spinal cord and nerve root vascular syndromes, 3) subacute encephalopathy, 4) peripheral or cranial neuropathies [13].

Initial diagnosis of stroke, encephalomyelitis, Guillain-Barré syndrome, vasculitis, and multiple sclerosis are often made, and the diagnosis of intravascular lymphomatosis is often not established until autopsy [14, 30-33].

Brain MRI shows abnormalities, such as multiple, metachronous cortical or subcortical lesions that are hyperintense on T2-weighted and fluidattenuated inversion recovery (FLAIR) images, suggestive of small vessel ischemia or demyelination. Cerebral imaging shows no characteristic features, but occlusive infarcts of multiple ages can usually be found. In some instances the disease can mimick vasculitis [15, 34-36].

Diffusion-weighted images (DWI) lesions either vanished or followed the typical pattern of an ischemic small vessel stroke with evolution of abnormal FLAIR signal followed by enhancement with gadolinium in the subacute stage and tissue loss in the chronic stage; DWI and FLAIR abnormalities proved to be partially reversible, correlating with the response to chemotherapy [34].

Some authors have defined five patterns of abnormal MR imaging findings: 1) infarct-like lesions (hyperintense areas on $\mathrm{T} 2 \mathrm{~W}$ with diffusion restriction), 2) nonspecific white matter lesions (poorly margined hyperintense lesions on T2W without mass effector abnormal enhancement), 3) meningeal enhancement (abnormal enhancement along the surface of the cortex with a pia-arachnoid pattern extending $>1$ gyrus in $>2$ planes on postcontrast T1-weighted images), 4) masslike 
lesions (intraparenchymal focal areas with contrast enhancement), and 5) hyperintense lesions in the pons on T2WI $[38,39]$. the brain.

The diagnosis may be provided by biopsies of

Macroscopically, the brain may show features of hemorrhage, thrombosis and necrosis.

Microscopically, the large tumor cells are localized in the lumina of small vessels and are characterized by vesicular nuclei and prominent nucleoli. Mitotic figures are frequently recognized. Malignant cells can only rarely be observed in the cerebrospinal fluid and the peripheral blood [40-42].

Cerebral biopsies may be falsely negative in neurological cases in which the diagnosis was confirmed post-mortem [43].

Intravascular lymphomatosis involvement of the skin consists in maculopapular eruptions, nodules, plaques, tumors, hyperpigmented patches, palpable purpura, ulcers, and infiltrating "peau d'orange" and have been misdiagnosed as cellulitis, gangrene, vasculitis, squamous cell carcinoma, and Kaposi's sarcoma [44].

Fever of unknown origin is seen in approximately $45 \%$ of cases with intravascular lymphoma, the diagnosis was established by a random skin biopsy $[45,46]$.

The Asian variant of intravascular lymphomatosis is considered a hemophagocytic syndrome, characterised by fever, anemia, thrombocytopenia, and hepatosplenomegaly. There is involvement of reticuloendothelial system and the bone marrow [47-50].

Anemia, elevated lactate dehydrogenase, and elevated erythrocyte sedimentation rate are the most common laboratory abnormalities seen in intravascular lymphomatosis. Thrombocytopenia and leukopenia are seen less often.

PET scan may identify subclinical involvement [51].
Diagnosis work-up should include random nerve, muscle, skin, and other biopsies. Because diagnosis based on other tissue than skin is usually difficult in patients with suspected intravascular lymphomatosis, random skin biopsy should be considered even in patients with no evident skin lesions [52, 53].

The recommended treatment of intravascular lymphomatosis is a chemotherapy regimen such Cyclophosphamide, Doxorubicin (Hydroxydaunomycin), Vincristin (Oncovin), and Prednisone (CHOP) with the addition of the monoclonal antibody Rituximab (R-CHOP) in cases with a B-cell immunophenotype. Additional Methotrexate may be necessary to improve the outcome when there is CNS involvement. In case of refractory intravascular lymphomatosis a second line therapy can be performed followed by autologous bone marrow transplantation or autologous peripheral stem cell transplantation. Plasmapheresis has been discussed as providing temporary benefit $[12,24,54-61]$.

In our case, clinical presentation of intravascular lymphomatosis was with skin lesions and subacute encephalopathy. The diagnosis was established post-mortem.

\section{CONCLUSION}

1) Intravascular lymphomatosis represents a difficult diagnostic challenge which involves laboratory, imagistic and immunohistochemical investigations.

2) Skin and sometimes brain biopsy is needed to establish the correct diagnosis.

Conflict of interest: The authors who have taken part in this study declared that they do not have anything to disclose regarding funding or conflict of interest with respect to this manuscript.

These authors contributed equally to this work.

Limfomatoza intravasculară este o afecțiune neoplazică multisistemică; aceasta este un subtip rar de limfom difuz cu celule mari caracterizat prin prezența celulelor limfomatoase în lumenul vaselor mici. O pacientă de rasă albă de 49 ani a fost internată în Clinica de Medicină Internă pentru astenie, transpirații nocturne, scădere ponderală şi multipli noduli la nivelul antebrațelor. În urmă cu trei luni familia pacientei a observat probleme cognitive şi dificultăți la indeplinirea activităților cotidiene. Examinarea neurologică a relevat bradipsihie. Examenele de laborator au evidentiat valori moderat crescute ale lactat dehidrogenazei şi proteinei $C$ reactive. A doua zi după internare pacienta a prezentat cefalee progresivă, starea mentală deteriorându-se şi redoare a cefei. Examenul LCR a relevat aspect hemoragic, 30 elemente/ $\mathrm{mm}^{3}$, citologie: limfocite 


\begin{abstract}
90\%, numeroase eritrocite, proteinorahie $96 \mathrm{mg} / \mathrm{dl}$, glicorahie $60 \mathrm{mg} / \mathrm{dl}$. S-au administrat metilprednisolon $(0,5 \mathrm{~g} \times 2$ pe zi) și manitol $20 \% 1 \mathrm{~g} / \mathrm{kg} / \mathrm{zi}$ timp de cinci zile fără răspuns. Pacienta a prezentat stare de comă şi a decedat după şase zile de spitalizare. Examinarea cerebrală macroscopică post-mortem a relevat creier edemațiat cu zone hemoragice difuze la nivelul regiunilor subcorticale supratentoriale. Examinarea microscopică a evidențiat capilare, venule și numeroase arteriole destinse de celule maligne mari sugerând limfocite maligne situate intraluminal. Toate organele erau afectate, cu excepția măduvei osoase şi a ganglionilor limfatici. Studiile imunohistochimice au relevat marcare intensă pentru limfocitele $B$ şi negativă pentru antigenul dependent de factorul VIII, marker specific al celulei endoteliale. Diagnosticul post-mortem a fost limfomatoză intravasculară. Acesta reprezintă o provocare diagnostică dificilă ce implică investigații de laborator, imagistice şi imunohistochimice.
\end{abstract}

Corresponding author: Inimioara Mihaela Cojocaru, $\mathrm{MD}, \mathrm{PhD}$, “Colentina” Clinical Hospital, Department of Neurology 19-21 Şos. Ştefan cel Mare, 020125, Bucharest, Romania

E-mail: inimioaracojocaru@yahoo.com

\title{
REFERENCES
}

1. GATTER K.C., WARNKE R.A. Intravascular large B-cell lymphoma. Pathology and genetics of tumors of haematopoietic and lymphoid tissues, Jaffe E.S., Harris N.L., Stein H., Vardiman J.W. (eds), 177-78, IARC Press: Lyon, 2001.

2. SUKPANICHNANT S., VISUTHISAKCHAI S. Intravascular lymphomatosis: a study of 20 cases in Thailand and a review of the literature. Clin Lymphoma Myeloma 2008; 6: 319-28.

3. CROISILE B., TOMMASI M., JOUVET A., TRUFFERT A., TRILLET M. Lymphome malin endovasculaire à grandes cellules. Rev Neurol (Paris) 1990; 146: 184-90.

4. WICK M.R., MILLS S.E. Intravascular lymphomatosis: clinico-pathologic features and differential diagnosis. Semin Diagn Pathol 1991; 8: 91-101.

5. YEGAPPAN S., COUPLAND R., ARBER D.A., WANG N., MIOCINOVIC R., TUBBS R.R., HSI E.D. Angiotropic lymphoma: an immunophenotypically and clinically heterogenous lymphoma. Mod Pathol 2001; 14; 1147-56.

6. MATSUE K., HAYAMA B.Y., IWAMA K., KOYAMA T., FUJIWARA H., YAMAKURA M., TAKEUKI M., O'UCHI T. High frequency of neurolymphomatosis as a relapse disease of intravascular large B-cell lymphoma. Cancer 2011; 117: 4512-21.

7. YAMADA S., TANIMOTO A., NABESHIMA A., TASAKI T., WANG K.-Y., KITADA S., NOGUCHI H., SASAGURI Y. Diffuse large B-cell lymphoma presenting with neurolymphomatosis and intravascular lymphoma: a unique autopsy case with diverse neurological symptoms. Diagnostic Pathology 2012; 7: 94.

8. KANDA M., SUZUMIYA J., OSHIMA K., TAMURA K., KOKUCHI M. Intravascular large cell lymphoma: clinicopathological, immuno-histochemical and molecular genetic studies. Leuk Lymphoma 1999; 34: 569-80.

9. PONZONI M., ARRIGONI G., GOULD V.E., DEL CURTO B., MAGGIONI M., SCAPINELLO A., PAOLINO S., CASSISA A., PATRIARCA C. Lack of CD29 ( $\beta_{1}$ integrin) and CD54 (ICAM-1) adhesion molecules in intravascular lymphomatosis. Hum Pathol 2000; 31: 220-26.

10. MACHADO G.F., CASTRO M.B., MELO G.D., FERREIRA W.L., AYLON E.G., ALESSI A.C. Intravascular lymphomatosis in the central nervous system of dogs: inmmunohistochemical investigation in two cases. Braz J Vet Path 2011; 4: 47-51.

11. OEI M.E., KRAFT G.H., SARNAT H.B. Intravascular lymphomatosis. Muscle Nerve 2002; 25; 742-6.

12. ZUCKERMAN D., SELIEM R., HOCHBERG E. Intravascular lymphoma: The Oncologist's "great imitator". The Oncologist hhttp://theoncologist.alphamedpress.org/

13. GLASS J., HOCHBERG F.H., MILLER D.C. Intravascular lymphomatosis. A systemic disease with neurologic manifestations. Cancer 1993; 71: 3156-64.

14. CALAMIA K.T., MILLER A., SHUSTER A., PERMICIARO C., MENKE D.M. Intravascular lymphomatosis. A report of ten patients with central nervous system and a review of the disease process. Adv Exp Med Biol 1999; 455: 249-65.

15. VIEREN M., SCIOT R., ROBBERECHT W. Intravascular lymphomatosis of the brain: a diagnostic problem. Clin Neurol Neurosurg 1999; 101: 33-6.

16. BEQUET D., GUILLAMO J.S., MOKHTARI K. Confrontation de la Salpetrière. Syndrome confusionnel, troubles de langaje, troubles moteurs des membre inferieures à rechutes chez un homme de 48 ans. Rev Neurol (Paris) 2000; 156: 821-27.

17. KONIKKARA J.J., PERURENA O.H., WARACH S., BAUSERMAN S.C. A 62-year-old man with fluctuating neurological deficits and skin lesions. JAMA Neurol 2013; 70: 120-24.

18. BILLÉ J., BILLÉ-TURC F., LEHMANN G., GAMBARELLI D., PADOVANI R., PELISSIER J.F. Un cas anatomo-clinique de demence au cours d'un lymphome endovasculaire à grandes cellules. Rev Neurol (Paris) 1995; 151: 576-79.

19. JOTPRATOOM P., YUCKPAN P., SITTHINASUWAN P., CHOTINAIWATTARAKUL W., CHINTHAMMITR Y. Progressive multifocal infarction from intravascular large B cell lymphoma presenting in a man: a case report. J Medical Case Reports 2011; 5: 24. 
20. AWAD A., ESTHPHAN B., STILVE O. CNS intravascular lymphoma: A case report. Case Reports in Neurological Medicine 2011; artcle ID 515182, 4 pages doi: 10.1155/2011/515182.

21. OJEDA V.J. Neoplastic angioendotheliosis of spinal cord. Case report. Acta Neuropathol (Berlin) 1983; 62: 164-6.

22. HAMADA K., HAMADA T., SATOH M., TASHIRO K., KATOH I., NAGANUMA M., SHIMA K., OGATA A., NAGASHIMA K. Two cases of neoplastic angio-endotheliomatosis presenting with mielopathy. Neurology 1991; 41: 1139-40.

23. DUBAS F., SAINT-ANDRE J.P., POULARD BARTHELAIZ A., DELESTRE F., EMILE J. Intravascular malignant lymphomatosis (so-called malignant angioendotheliomatosis): a case confined to the lombosacral spinal cord and nerve roots. Clin Neuropathol 1990; 9: 115-20.

24. NAKAHARA T., SAITO T., MUROI A., SUGURA Y., OGATA M., SUGIYAMA., YAMAMOTO T.A. Intravascular lymphomatosis presenting as an ascending cauda equina: conus medullaris syndrome: remission after biweekly CHOP therapy. J Neurol Neurosurg Psychiatry 1999; 67: 403-6.

25. ABUZINADAH A., ALMALIK Y., SHABANI-RAD M.-T., HO C.H., GEORGE D., ALANT J.,ZOCHODNE D. Cauda equina syndrome secondary to intravascular lymphoma. Neurology Clinical Practice 2012; 2: 158-61.

26. ROUX S., GROSSIN M., DE BRANDT M., PALAZZO E., VACHON F., KAHN M.F. Angiotropic large cell lymphoma with mononeuritis multiplex mimicking systemic vasculitis. J Neurol Neurosurg Psychiatry 1995; 58: 363-6.

27. VANDENHEEDE M., DIOH A., DE NOORDHOUT M., DEPREZ M., SCHOENEN J. Intravascular malignant lymphomatosis: report of 2 cases. Acta Neurol Belg 2002; 102: 76-81.

28. LEVIN K.H., LUTZ G. Angiotropic large-cell lymphoma with peripheral nerve and skeletal muscle involvement: early diagnosis and treatment. Neurology 1996; 94: 311-5.

29. MATSUE K., HAYAMA B.Y., IWAMA K.-I., KOYAMA T., FUJIWARA H., YAMAKURA M., TAKEUCHI M., O’UCHI T. High frequency of intravascular neurolymphomatosis as a relapse disease of intravascular large B-cell lymphoma. Cancer 2011; 117: 4512-21.

30. HSU Y.H., TSENG B.Y., SHYU W.C., YEN P.S. Intravascular lymphomatosis mimicking acute disseminated encephalomyelitis: a case report. Kaohsiung J Med Sci 2005; 21: 93-7.

31. LEGERTON C.W. 3rd, SERGENT J.S. Intravascular malignant lymphoma mimicking central nervous system lupus. Arthritis Rheum 1993; 36: 135.

32. FREDERICKS R.K., WALKER F.O., ELSTER A. Angiotropic intravascular large-cell lymphoma (malignant angioendotheliomatosis): report of a case and review of the literature. Surg Neurol 1991; 35; 218-23.

33. SUMER M., OZON A.O., BAKAR B., CILA A., RUACAN S. Intravascular lymphoma masquerading as multiembolic stroke developing after coronary artery by-pass surgery. Neurologist 2009; 15: 98-101.

34. BAEHRING J.M., LONGTINE J., HOCHBERG F.H. A new approach to the diagnosis and treatment of intravascular lymphoma. J Neurooncol 2003; 61: 237-48.

35. SONG D.K., NOULIS N.M., MCKEEVER P.E., QUINT D.J. Angiotropic large cell lymphoma with imaging characteristics of CNS vasculitis. Am J Neuroradiol 2002; 23: 239-42.

36. LIOW U., ASMAR P., LIOW M. Intravascular lymphomatosis: contribution of cerebral MRI findings to diagnosis. J Neuroimaging 2000; 10: 116-8.

37. BAEHRING J.M., HENCHCLIFFE C., LEDEZMA C.J., FULBRIGHT R., HOCHBERG F.H. Intravascular lymphoma: magnetic resonance imaging correlates of disease imaging dynamics within the central nervous system. J Neurol Neurosurg Psychiatry 2005; 76: 540-4.

38. YAMAMOTO A., KITUCHI Y., HOMMA K., O’UCHI T., FURUI S. Characteristics of intravascular large B-cell lymphoma on cerebral MR imaging. AJNR 2012; 33: 292-6.

39. WILliaMS R.I., MELTRER C.C., SMIRNIOTOPOUlOS J.G.,FUKUI M.B., INMAN M. Cerebral MR imaging in intravscular lymphomatosis. AJNR 1998; 19: 427-31.

40. HUNG L.-C., TSAI J.-H., WU C.-S., DAI Y.-C., CHEN C.-C., SUNG S.-F. Brain biopsy-proven intravscular lymphomatosis presenting as rapidly recurrent strokes-two case reports. Acta Neurol Taiwan 2014; 23: 11-8.

41. SCULLY R.E., MARK E.J., MCNEELY W.F., EBELING S.H. Case records of the Massachusetts General Hospital. N Engl J Med 1996; 335: 952-9.

42. OSSEGER L.M., POSTLER E., PLEGER B., MULLER K.-M., MALIN J.-P. Neoplastic cells in the cerebrospinal fluid in intravascular lymphomatosis. J Neurol 2000; 247: 656-8.

43. BILLÉ J., BILLÉ-TURC F., LEHMANN G., GAMBARELLI D., PADOVANI R., PELISSIER J.F. Un cas anatomo-clinique de demence au cours d'un lymphome endovasculaire à grandes cellules. Rev Neurol (Paris) 1995; 151: 576-9.

44. FERRERI A.J.M., CAMPO E., SEYMOUR J.F., WILLEMZE R., ILARIUCCI F., AMBROSETTI A., ZUCCA E., ROSSI G., LOPEZ-GUILlERMO A., PAVLOVSKY M.A., GEERTS M.-L., CANDONI A., LESTANI M., ASIOLI S., MILANI M., PIRIS M.A., PILERI S., FACCHETTI F., CAVALLI F., PONZONI M., ON BEHAF OF THE INTERNATIONAL EXTRANODAL LYMPHOMA STUDY GROUP (IELSG). Intravascular lymphoma: clinical presentation, natural history, management and prognostic factors in a series of 38 cases, with special emphasis on the "cutaneous variant". Br J Haematol 2004; 127: 173-83.

45. GILL S., MELOSKY B., HALEY A. Use of random skin biopsy to diagnose intravascular lymphoma presenting as fever of unknown origin. Am J Med 2003; 114: 56-8.

46. KIDSON-GERBER G., BOSCO A., MACCALUM S., DUNKLEY S. Two cases of intravascular lymphoma: highlighting the diagnostic difficulties in pyrexia of unknown origin. Intern Med J 2005; 35: 569-70.

47. MURASE T., NAKAMURA S., KAWAUCHI K., MATSUZAKI H., SAKAI C., INABA T., NASUN K., TASHIRO K., SUCHI T., SAITO H. An Asian variant of intravascular large B-cell lymphoma: clinical pathological, and cytogenetic approaches to diffuse large B-cell lymphoma associated with haemophagocytic syndrome. Br J Haematol 2000; 111: 826-34. 
48. MURASE T., NAKAMURA S., TASHIRO K., SUCHI T., HIRAGA J., HAYASAKI N., KIMURA N., SAITO H. Malignant histiocytosis-like B-cell lymphoma, a distinct pathologic variant of intravascular lymphomatosis: a report of five cases and review of the literature. Br J Haematol 1997; 99: 459-73.

49. MURASE T., NAKAMURA S. An Asian variant of intravascular lymphomatosis: an updated review of malignant histiocytosislike B-cell lymphoma. Leuk Lymphoma 1999; 33: 459-73.

50. NINOMIYA T., NAKAMURA T., FUJI N., HIRAKI A., IMEMURA S., YAMANE H., SHIRAKAWA A., KAMEI H. Unusual spontaneous improvement in Asian variant of intravascular large B-cell lymphoma. Open Journal of Internal Medicine 2012; 2: $15-8$.

51. HOSHINO A., KAWANDA E., UKITA T., ITOH K., SAKAMOTO H., FUJITA K.,MANTANI N., KOGURE T., TAMURA J. Usefulness of FDG-PET to diagnose intravascular lymphomatosis presenting as fever of unknown origin. Am J Haematology 2004; 76: 236-9.

52. ASADA N., ODAWARA J., KIMURA S., AOKI T., YAMAKURA M., TAKEUKI M., SEKI R., TANAKAN A., MATSUE K. Use of random skin biopsy for the diagnosis of intravascular large B-cell lymphoma. Mayo Clin Proc 2007; 93: 1525-7.

53. OOMURA M., SAKAKIBARA N., SUZUKI S., WAKITA A., MORI Y., KAMIMOTO K. Intravascular lymphomatosis mimicking primary central nervous system lymphoma: A case report and literature review. Case Reports in Neurology 2014; 6: 101-8.

54. BAUMANN T.P., HURWITZ N., KARAMITOPOLOU-DIAMANTIS E., PROBST A., HERRMANN R. Diagosis and treatment of intravascular lymphomatosis. Arch Neurol 2000; 57: 374-7.

55. SHIMADA K., KINOSHITA T., NAOE T., NAKAMURA S., Presentation and management of intravascular B-cell lymphoma. Lancet Oncol 2009: 10: 895-902.

56. HARRIS C.P., SIGMAN J.D., JAECKLE K.A. Intravascular malignant lymphomatosis: amelioration of neurologic symptoms with plasmapheresis. Ann Neurol 1994; 35; 357-9.

57. NAKAHARA T., SAITO T., MUROI A., SUGIURA Y., OGATA M. Intravascular lymphomatosis presenting as an ascending cauda equina conus medularis syndrome: remission after biweekly CHOP therapy. J Neurol Neurosurg Psychiatry 1999; 67: 403-6.

58. ROSE C., STAUMONT D., JOUET J.-P. Successful autologous bone marrow transplantation in intravscular lymphomatosis. Br J Haematol 1999; 105: 313-20.

59. BAEHRING J.M., LONGTINE J., HOCHBERG F.H. A new approach to the diagnostic and treatment of intravascular lymphoma. J Neurooncol 2003; 61: 237-48.

60. ANGHEL G., PETRINATO G., SEVERINO A., REMOTTI D., INSABATO L., DE RENZO A., ROTOLI B., MAJOLINO I. Intravascular B-cell lymphoma: report of two cases with different clinical presentation but rapid central nervous system involvement. Leuk Lymphoma 2003; 44: 1353-9.

61. INOUE D., HAMAMURA T., UEHARA T., MIYOSHI K., KATSURAGI T., TAKESHITA I., HAMATA T. Intravascular lymphoma confirmed by brain biopsy, quickly treated by chemotherapy: a case report. No Shinkei Geka 2008: 37: 369-74.

62. SAWAMOTO A, NARIMATSU H., SUZUKI T., KURAHASHI, SUGIMOTO T., SUGIURA I. Long-term remission after autologous peripheral blood stem cell transplantation for relapsed intravascular lymphoma (Letter). Bone Marrow Transplantation 2009; 37: 233-4.

Received March 15, 2015 